Journal of the Textile Institute Proceedings and Abstracts

\title{
YORKSHIRE SECTION: Meeting at Bradford, 28th October, 1920. Mr. George Garnett in the Chair. THE INFLUENCE OF THE FISHER EDUCATION BILL ON THE TEXTILE INDUSTRY
}

Alderman P. R. Jackson J.P.

To cite this article: Alderman P. R. Jackson J.P. (1920) YORKSHIRE SECTION: Meeting at Bradford, 28th October, 1920. Mr. George Garnett in the Chair. THE INFLUENCE OF THE FISHER EDUCATION BILL ON THE TEXTILE INDUSTRY, Journal of the Textile Institute Proceedings and Abstracts, 11:11, 313-316, DOI: 10.1080/00405002008631162

To link to this article: http://dx.doi.org/10.1080/00405002008631162

曲 Published online: 24 Nov 2008.

Submit your article to this journal $₫$

山 Article views: 3

Q View related articles ¿ 
Results of Investigations : Any useful results obtained from investigations should be made known-particularly to overlookers and machinists - at the earliest opportunity, so that the advantage of means to reduce noise might be immediately available for adoption.

Dr. Kent is now engaged on some investigations for recording the noise made by various moving parts of the loom, and is endeavouring to ascertain how far use is capable of modifying the effect of noise upon any particular individual and whether such insuscepti. bility can be increased; also what intensity and what kind of noise is most injurious, what means can be taken to avoid this particular kind of noise in practice, and how far massive vibration can be separated from noise.

\section{YORKSHIRE SECTION}

Meeting at Bradford, 28th October, 1920.

Mr. George Garnetr in the Chair.

\section{THE INFL.UENCE OF THE FISHER EDUCATION BILL ON THE TEXTILE INDUSTRY}

By County Alderman P. R. JACKson, J.P.

(Chairman of West Riding Education Committee, and Member of the Consultative Committee of the Board of Education).

The Fisher Act of Parliament is a great Act. It does not deal entirely with the continued education of young people; it does a great deal more than that. There are a number of things within the Act which have already come into operation, and amongst other things a local authority is not restricted in its expenditure on scholarships. Previously, the County authorities have been limited by a $3 \mathrm{~d}$. rate for Higher Education. but now they are not limited, and the West Riding Authority is determined not to limit its scholarships to the secondary schools. The scholarships are thrown open to all boys and girls who are capable of passing the necessary examination, and the numbers in the first year have nearly doubled. Half-time is to go. That affects the textile industry and Bradford very largely. Fourteen years is to be the age for leaving school. That portion of the Act which refers to the leaving age and to half-time is to come into operation at the end of this year. For the last year of education at school the authorities have to provide a great deal more handwork within the schools than exists at the present time. They are bound to find a certain proportion of handwork for all boys and girls who are staying at school. Mr. Garnett asked me an important question just now as to whether or not I thought we were teaching too many subjects in the schools to-day, and that could not the subjects be reduced in number and a fow taught more thoroughly. That reduction is not contemplated, and it is very probable that with the introduction of more handwork additional subjects will have to be undertaken. The boys and girls of the old days of the "Three R's" were probably better spellers and arithmeticians than the boys and girls of to-day, but education is not intended only to make a boy spell. It is to train his brain so that he can go forward and educate himself from point to point as he grows up in life. The boys leaving school to-day are of far greater intelligence than in the old days of eramming arithmetic, \&c.

We have to read a great deal more into handwork than before. It does not mean only woodwork for the boys and cookery for the girls. The Labour Party in the West Riding County Council are very much up in arms against handwork in education. They say we are out to train the boys to be tradesmen, and they say that if the sons of the employers are to have a classical education so must the sons of the workers. The reply to that argument is that the purpose of handwork is not vocational training. The headmaster of Oundle School-probably the most progressive school of the time-lays great stress on handwork, and has said that we can teach the humanities through handwork as well as through Homer. In the hands of a teacher without imagination or intelligence, the loom would be as dryasdust, and the Labour Party might be correct in saying the authorities were only teaching the boy to be a weaver, but in the hands of a teacher who has imagination, intelligence, and education the story of the loom might be used to teach a boy as much about humunities as can belearned through Homer. Only a very few boys are bookworms, yet if we put a boy to make a rabbit-hutch or a pigeon-cote that boy will put his whole soul into it. We have got to take hold of that fact and educate the boy round it. Contrary to the opinion of the Labour Party in the Council, I say that we are going to teach nine boys out of every ten more out of their hands if we have properly imaginative masters than we can do out of their books. By the Fisher Act it is made compulsory that hand. work should enter very largely into the training of boys and girls. The Act also gives the authorities powers to develop the physical education of the young people, and the authorities may rent or purchase playing fields-10 acres if they like. The idea now is, in building new schools, to get hold of twenty acres of land, so that they should have fields where physical training and games can be enjoyed just as they are at the public schools.

The Bill does not give the authorities power to build village halls and fit them up for village industry, but it gives them power to spend money in the villages in developing village life within a hall already provided. If the people of the village will provide the hall, the authorities can find the money necessary to train the people in village industries. I know a good deal about hand looms, and I am a bit sceptical when I hear people speak about the big future for hand looms. The power loom always comes along and does better than the hand loom. The power loom weaves more regularly and puts a firmer back on the fabric than a hand loom can passibly do. There is, however, an opening for village industries to-day, especially in colliery districts where the women have nothing before them but domestic service, and the establishment of village industries in these districts would be morally and economically good. For instance, why not send pieces to mend from Bradford to the villages when there is a shortage of menders in Bradford ? The Act would enable us to train women in the villages in mending and fine drawing. 
When I first went to business the employers paid about 16s. a week for men, and what they wanted was men strong in the back but weak in the head. Those days are gone altogether, and there is not only a recognition of proper wages, but there is a greater sympathy between the capitalistic class and the workers to-day than has ever existed before. It has taken until the 20th Century to bring into operation that sympathy between class and class which was taught in the Sermon on the Mount. I believe, however, that there is more sympathy on the part of the employer to the employed than there is from the employed to the employer, and it needs a great move on the part of the employee towards the employer to meet the movement that has come from the employer to the employed. If that movement will come, not only will the Fisher Act come in its entirety, but it will bring solution to the industrial problems that seems at present almost impossible.

It is not possible to fix at the present time a date for the bringing into operation of compulsory continued education beyond the age of fourteen, and 1 am of opinion that it cannot come fully for some years. It is estimated that if the West Riding Authority is to build part-time continuation schools, as required by the Act, and provide the teachers necessary, it will cost $£ 5,000,000$. Even if the Authority is prepared to undertake the building of these schools it cannot spend the money, as it is impossible to get the necessary builders, masons. \&c. It is laid down in the Act that boys and girls who attend school full time until they are sixteen years of age need not have part-time education after leaving school, and the West Riding County Council are putting their money upon full-time education. We have told the Board that we intend to build central schools, to keep the boys first until they are fifteen and, later, until sixteen, rather than go in for part-time continuation work. Continuation work means that the boys and girls until they are sixteen, and, later, until they are eighteen, must put in $320 \mathrm{hrs}$. per year of part-time education. I hold that if we are going to give the boys and girls a whole-time education until they are sixteen, it is very much in advance of one day's education in the week until they are eighteen. From a psychological standpoint, too, it is far better. Boys and girls at fourteen come to an age when a great psychological change takes place, and these children are pitchforked into the mills and mines at a time when they are spiritually and morally beginning to awaken and are physically undergoing a tremendous change. We are throwing these young people into an atmosphere which is not all it should be. Two half-days a week at school will not move the balance against the influence of the mill or pit, and the influence of the mill or pit will outweigh the good of the two half-days a week at school. It is a remarkable thing that, however much the middle classes grumble at the education rate, they are all sending their boys and girls to the best schools and are denying themselves to do so. If that is right for one boy or girl it is right for the other, and as part-time education is not equal to full-time education let us go for what is best.
It is no use saying that part-time education is not feasible in any business; it is feasible in some. A good many engineering firms have a part-time voluntary education system in operation in their works, so that it is no use saying it is impossible.

At my own works we have twenty persons under eighteen years of age working double-plush looms, which are very intricate indeed. I have tried to think out what will happen if we have to send them to a compulsory part-time school. We should have to divide the twenty into five parties, and four persons would be away each day. We could not afford to keep the looms standing idle as the cost would be too great, and we could not replace the boys and girls with other boys and girls because a loom will go with one person and yet not with another. We should have to get four of the very best people we could, and they would have to be kept as a floating four, being put on to work a fresh loom every day. We could not put them on piece rates, and we should have to pay them not less than $£ 5$ per week. That means we shall have to pay $£ 20$ a week to replace the boys and girls whilst they are at school. If we multiply that by fifty weeks we get a rough figure of $£ 1,000$ a year. My firm can not afford to pay that amount, and it is unfair to try and make us afford it. It is not our call, but the nation's call to educate the young people, and it is wrong to ask us to find the money and put it upon the price of our cloth. It is not good for industry.

Looking at the matter from another standpoint, however, these twenty boys and girls could go wholetime to the secondary school at a cost to the nation of f500, yet it will cost us twice the sum to send each boy and girl two half-days each week to school than it will if we send them full-time to the secondary school until they are sixteen. When boys and girls arrive at the age of sixteen they are capable of looking upon education from quite a different standpoint than when they are fourteen. In these two years they get some idea of what beauty and idealism mean. They have begun to enter life with a different prospect than the boys and girls drafted into industry at fourteen years of age. Education means something more than learning to earn a living, and if a boy or girl is condemned to the mill or pit at the age of thirteen or fourteen, we are going to make it impossible for them to attain to that standard of education that the employers claim for their own children. There is a tendency to shorten the number of working hours, and I think that the boys and girls when over sixteen will be able to spare a couple of hours of the winter evenings for attendance at the technical schools as they have done in the past. We will have exceptions, but I do not think it is feasible from the standpoint of industry to make part-time technical education compulsory after sixteen years of age. The authorities might experiment in that way, but I think they would have to give it up. The Germans have tried something of that sort, but it came to the fact that part-time education was being given on Saturday and Sunday. We, in England, are not going to get our young people to go to school on Saturdays and Sundays. 
I think we in the West Riding will do right to put our money upon central schools. London has already gone in for central schools. I have examined the work of these schools, and you may take it that the central schools in London are doing excellent work and give as much in the way of education as the Bradford Secondary School. At the London Central Schools they find that for every boy leaving school they have a number of applications from employers, and the boys are taken up as fast as they leave school. Every one of the secondary schools in the West Riding is full to overflowing. The authority propose to put up central schools, and give scholarships and maintenance allowances to those people who can not afford to send their children. In my opinion, the future of continued education, apart from those who are to enter the professions, is in the central schools, and I do not think part-time education as a general education is feasible. You know your own businesses best. You have got to think the matter out, and if you find it cannot be done now is the time to say so.

\section{Discussion.}

The Chatrman said he had received a communica. tion from the Director of Education for Bradford expressing regret that he was unable to be present that evening. The director could give no definite pronouncement on the matter they were considering, as his Committee had not yet got very far with the scheme. They had not considered the provision of buildings, but the director thought they might probably have to adopt the army hut principle to a certain extent. They had with them that evening $\mathrm{Mr}$. Richardson, the recently-appointed Principal of the Bradford Technical College, and he would like to take that opportunity of welcoming him to their meetings. They were ready to help him in every way to further the work he had undertaken at the College.

Mr. Richardson thanked the Chairman for the offer of help, and said the College could not get on without the help of men such as the members of the Yorkshire Section of the Textile Institute. It was no good the Technical College existing if it was going to run itself purely as an educational institution with. out attempting to produce some result that the manufacturers might want. If they at the College did not know what the manufacturers wanted they could do nothing. He was interested in the continuation schools rather from the standpoint of what they were going to provide the technical colleges with later on. $\mathrm{He}$ thought that even if there was going to be no education during the day after the boys and girls had reached sixteen years of age, there was going to be all the more demand for higher education. He thought there was going to be a great increase all round in that respect, because the value of that education was seen in their daily work. In the past, a very large proportion of the young people between the ages of fourteen and sixteen had gone backward in their education, and he anticipated quite confidently that within a very few years of the establishment of continuation schools they would have a very large demand for higher education. The technical schools did not get the very best results at present because they had got to begin lower down the educational scale and make sure that a certain amount of work must be done that ought to have been done before the students came to the schools. He thought there was a lot to be said for central schools and also a lot for part-time schools. There was one type of boy who would do well at a secondary school, another type who would do best at a central school, and there was another type who would fit into a part. time continuation school because his brain was a little less than the other types. It was not easy to provide for the three types, and if they adopted only the central school system he was afraid there would be difficulty. To his mind, people speaking on the Act underestimated the difficulty of the supply of teachers. The aims they all had in view, viz. $(a)$ to make a man an excel. lent citizen, and $(b)$ to make him a capable and useful man for his employer, were bound up very closely indeed with the man who was to teach. They must first tackle the problem of the man who was to teach. for if they got the right man they could get the right results. If they went cautiously and made sure they were on the right lines they would have very great results.

Mr. Pfarce (Devon) said he felt very strongly that the Bill had cnormous potentialities which he hoped would, in the near future, be brought into realisation. If they could bring brain to bear upon an industry they were going to get far better results, and the better educated a nation became the better that nation would be. They had difficulty in Devon in starting the continuation schools, and they had been told by one firm with three or four small factories that if they agreed to a part-time scheme they would be handicapping themselves against competitors. One school had been startid, and he hoped it would be an object lesson to other industries in the district. There was a demand for higher education, and that demand must be supplied. If the public demand it, they must be prepared to foot the bill. He confessed considerable surprise that so huge a Bill had been passed without any real organised opposition, and it led him to believe that there was a real desire throughout the country to have that intensified education in the future.

Mr. A. M. BELL (Halifax) suggested that the scholars who were likely to enter the industry might be led gently into textile work by a simple introduction to the various machine operations and the materials passing through the machines, with the pointing out of certain influences which arise as the materials are passing through the machines. He thought that in the last two years of school career some of the handwork should have a special bearing upon the various local industries, and he felt that the history of their various industries was quite as interesting and important as studying some of the classics people laid such great stress upon.

A speaker expressed the opinion that, in certain occupations, when a girl left school at sixteen her fingers would have become so stiff that she would not be able to do the work required of her.

In reply, Alderman JAckson said he did not wish to imply that there would be less technical school work 
after the boys and girls were sixteen years of age. He agreed there would be very much more after sixteen if they got the young people better educated up to sixteen. He did not agree that some boys were not fitted for the different schools intended, and they could not say that there were boys and girls who could do no good by going to school after they were fourteen. He quite agreed that the supply of teachers was the be-all and end-all of the great work. It was intended to give the teachers a salary which was something like adequate for the work they had to do, and with the intended scale it was his opinion that the teaching profession was going to be one of the best professions in the country. It must be recognised that the teaching profession was an important profession, and they must pay for it accordingly. It was essential that the schoolmaster must have a wide view and a great con- ception. He agreed that the trade of the diatrict ought to have a place in the school curriculum but not wo teach children to be artisans. He did not agree that the fingers of girls at sixteen would be less supple than at fourteen. His firm employed a number of girls of sixteen in place of half-timers, and they got better work whether their fingers were supple or not.

In proposing a vote of thanks to the lecturer, Mr. F. Anderson (Bradford) said that when the Act came into force to the full extent it would be bound to affect the textile industry very seriously. It might affect the spinning branch of the industry more than any other, and if iv affected that branch so as to tend to restrict production, it would affect the other branches.

Prof. E. Midaley (Bradford) seconded, and the thanks of the meeting were heartily accorded.

\section{GENERAL PROCEEDINGS, AND REPORTS}

\section{THE TEXTILE TRADE AND INDUSTRY OF GREECE, NORWAY AND HOLLAND}

Reports on the commerce and industry of Greece, Norway and Holland, by the Commercial Secretaries attached to H.M. Legations at Athens, Christiania, and the Hague, have been issued by H.M. Stationery Office (Greece, Cmd. 793, price 4d. net; Norway, Cmd. 839, price 1s. net; Holland, Cmd. 872, price 1s. net). The reports contain a general survey of the economic conditions obtaining in each country, and a good deal of information has been collected relating to the textile trade and industry.

In Greece an attempt was made, in 1919 , to foster the domestic cotton industry and at the same time encourage the cultivation of cotton. This was done by means of a Royal Decree prohibiting the import of raw cotton, cotton thread (up to No. 24's) and coloured cotton cloths. The protection given by the measure did not compensate the industry for the loss of American and Egyptian cotton, and manufacturers and merchants were successful in getting it repealed. The textile industry in Greece appears to be expanding ; there are now about 75 cotton spinning mills at work, and it is expected that more will be erected shortly. An increase has also taken place in the number of mills producing flannel and hosiery, the bulk of the woollen yarns for which are imported from Great Britain. The dye industry at Piræus is handicapped by the prohibition of the export of dye materials from the United Kingdom. Before the war supplies were obtained from Germany. In 1919 a successful strike was carried out by the textile factory workers at Athens and Piræus.

The Norwegian textile industry experienced great difficulty in getting sufficient supplies of raw material during the war. After the autumn of 1914 it was impossible to get woollen yarns from Germany, and England was the only source of supply ; in May, 1917, imports ceased entirely. All the material in the country was rationed, which enabled some machinery to be kept running, but many factories had to close down. In February, 1919, imports from England were resumed : in June all control of imports of wool and woollen yarns was abolished and export only allowed when the consent of the Government had been obtained. The cotton industry experienced much the same difficulties, the ration of cotton and cotton yarn allowed by the British Government during 1915-6 being insufficient to keep the mills running full time. In the autumn of 1917, imports ceased, and many mills were compelled to close. A few months after the Norwegian-American Agreement sufficient supplies were obtained and mills were running full time again. The high wages offered in other occupations have diminished the supply of labour available for textile factories, and the rates of wages have risen four or five times higher than pre-war rates. Norway imports large quantities of textile goods and before the war these came principally from Great Britain, Germany, and France. The German imports were maintained until 1916 and then ceased. At the same time great difficulty was experienced in obtaining goods from this country and importers bought heavily in America. This trade was stopped in the autumn of 1917 , but resumed after the agreement of 1918 . When war conditions were over importers still bought American cotton yarns because prices were lower than the prices of British yarns, but recently American prices have been rising, and it is hoped that trade will revert to its usual channels. It is believed that America will retain the trade in hosiery and cotton underelothing until German industry revives, but the main portion of the trade in piece-goods, formerly done by Germany. appears to have been transferred to British firms, The suggestion is made that in order to retain this trade British manufacturers should have their own representatives in Norway instead of selling to export houses. In dress goods and linen goods British manufacturers have not shown much anxiety to cater for Norwegian taste; in woollen hosiery the tariff is against them, in cotton hosiery they cannot compete with America. The demand for curtainettes, velveteens, woollen tapestries, and table covers is good, and there is a big demand for Axminster and Wilton carpets.

The report on Holland is confined to conditions in 1919. During the first six months of the year the textile industry was slack. the home demand being very small and raw materials difficult to obtain. During the latter half of the year trade improved, but 